\title{
Nanoparticles Equipped with $\alpha 2,8$-Linked Sialic Acid Chains Inhibit the Release of Neutrophil Extracellular Traps
}

\author{
Kim F. Bornhöfft ${ }^{1,2}$, Torsten Viergutz ${ }^{1}$, Andrea Kühnle ${ }^{1,2}$ and Sebastian P. Galuska ${ }^{1,2, *(D)}$ \\ 1 Institute of Reproductive Biology, Leibniz Institute for Farm Animal Biology (FBN), Wilhelm-Stahl-Allee 2, \\ 18196 Dummerstorf, Germany; bornhoefft@fbn-dummerstorf.de (K.F.B.); \\ viergutz@fbn-dummerstorf.de (T.V.); kuehnle@fbn-dummerstorf.de (A.K.) \\ 2 Faculty of Medicine, Institute of Biochemistry, Justus-Liebig-University, Friedrichstrasse 24, \\ 35392 Giessen, Germany \\ * Correspondence: galuska.sebastian@fbn-dummerstorf.de; Tel.: +49-38208-68-769; Fax: +49-38208-68-752
}

Received: 5 February 2019; Accepted: 2 April 2019; Published: 12 April 2019

\begin{abstract}
Neutrophils can combat the invasion of pathogens by the formation of neutrophil extracellular traps (NETs). The NET mechanism is not only an effective tool for combating pathogens, but is also associated with diseases. Therefore, NETs are a potential target for combating pathologies, such as cystic fibrosis and thrombosis. We investigated the potential of nanoparticles, which were modified with $\alpha 2,8$-linked sialic acid chains, to modulate NET release during phorbol myristate acetate stimulation. Interestingly, when these nanoparticles were applied, the formation of reactive oxygen species was partly inhibited and the release of NET was counteracted. However, although the release of NET fibers was prevented, the nuclei still lost their characteristic segmented structure and became swollen, indicating that only the release, and not complete activation was suppressed. Intriguingly, coincubation of $\alpha 2,8$-sialylated particles with free sialic acid chains prevented the outlined inhibitory effects. Thus, the sialic acid chains must be attached to a linker molecule to generate an active bioconjugate that is able to inhibit the release of NET.
\end{abstract}

Keywords: neutrophil; NETosis; reactive oxygen species (ROS); innate immunity; sialic acids; siglecs; polysaccharide

\section{Introduction}

Neutrophil granulocytes are the most abundant leukocytes of the innate immune system representing the first line of defense against invading pathogens [1-3]. In the case of inflammation, these granulocytes exit the circulation system via trans-endothelial migration, a selectin-driven mechanism [4]. Arriving at the inflammation site, they release reactive oxygen species (ROS), as well as antimicrobial peptides and phagocytose pathogens, such as bacteria.

Moreover, in 2004, Brinkmann and colleagues discovered that neutrophils can undergo beneficial suicide, resulting in the release of neutrophil extracellular traps (NETs) [5]. The DNA fibers released are associated with numerous antimicrobial components [5-8]. The formation of NETs can be induced by pathogens, such as bacteria, fungi, and viruses, as well as by chemical stimuli, such as calcium ionophore A23187 or phorbol myristate acetate (PMA) [9-12]. When the formation of NETs is induced by PMA, calcium influx from the endoplasmic reticulum is induced and protein kinase $C$ alpha (PKC) is activated. PKC initiates the activation of the Raf-MEK-ERK pathway. ERK1/2 seems to activate nicotinamide adenine dinucleotide phosphate (NADPH) oxidase by phosphorylation, contributing to the activation of the NADPH oxidase enzyme complex [4,9,13-15]. This complex produces ROS, which are enzymatically converted to hypochlorous acid $(\mathrm{HOCl})$ by myeloperoxidase $[4,9]$. This leads 
to the transfer of neutrophil elastase to the nucleus, where neutrophil elastase degrades histones, such as histone H4, promoting the decondensation of DNA. During the last step, granular vesicles, in addition to plasma membranes, rupture and a mixture, which consists of antimicrobial biomolecules (e.g., myeloperoxidases, neutrophil elastases, lactoferrin, defensins, and cytotoxic histones) is released to combat the invading pathogens $[9,16]$.

In addition to beneficial effects, the formation of NET is associated with diseases, such as infertility, small-vessel vasculitis, rheumatoid arthritis, preeclampsia, ulcerative colitis, Crohn's disease, systemic lupus erythematous, thrombosis, and cystic fibrosis [9,17-23]. Thus, the inhibition of an exaggerated NET release is an opportunity to combat these pathologies.

In mammals, several biomolecules have the capacity to modulate immunological mechanisms. Since all our cells are surrounded by a glycocalyx, consisting of glycolipids and glycoproteins, glycan-dependent mechanisms frequently take place during processes of innate and adaptive immunity [24]. In mammals, glycans are often terminated with sialic acid residues [25]. These sialylated structures can be recognized by immune cells using, for example, sialic acid-binding immunoglobulin-like lectins (siglecs), which are important immunoregulatory elements in vertebrates [26-29]. Intriguingly, inhibitory siglecs can counteract kinase-dependent activation of immune cells by recruiting SHP1 and SHP2 [28,30]. For example, Varki and colleagues described that, in the bloodstream, siglec-9 on neutrophils inhibits neutrophil activation by binding sialylated glycoproteins on erythrocytes [31]. Thus, siglecs became a target for modulating immunological events [32]. One possibility is to decorate nanoparticles with sialylated glycans. For instance, Spence et al. showed that nanoparticles coated with dimers of $\alpha 2,8$-linked sialic acid residues, which are the ligand for murine siglec-E, decreased inflammation driven by lipopolysaccharide (LPS) in murine macrophages [33]. Human neutrophils are known to express siglec-3, $-5,-9$, and -14 , and interestingly, siglec-5 is able to recognize $\alpha 2,8$-linked sialic acid residues, such as siglec-E in mice [34-36].

Thus, we hypothesized that $\alpha 2,8$-linked sialic acid residues can be used to modulate the activation of neutrophils and NETosis. The obtained results demonstrate that the release of NETs is inhibited by the application of particles containing $\alpha 2,8$-linked sialic acid chains, indicating that $\alpha 2,8$-sialylated nanoparticles are a tool for manipulating the formation of NET.

\section{Materials and Methods}

\subsection{Materials}

Endoneuraminidase (endoN) was kindly provided by Martina Mühlenhoff (Medizinische Hochschule, Hannover, Germany) [37]. All reagents used were of analytical grade.

\subsection{Human Neutrophils}

All volunteers provided written informed consent and all samples were anonymized. The use of human neutrophils was approved by the local ethics office of the University of Giessen, School of Medicine (05/00).

\subsection{Digestion and Fractionation of Sialic Acid Chains}

$10 \mathrm{mg}$ colominic acid (Gerbu, Heidelberg, Germany) was digested via the use of endoN (4.46 $\mu \mathrm{g}$ $\left.\mathrm{mL}^{-1}, 2 \mathrm{~h}, 37^{\circ} \mathrm{C}, 250 \mathrm{rpm}\right)$. Resulting cleavage products were separated and collected according to the degree of polymerization (DP) by anion exchange chromatography, as described earlier, to get sialic acid chains with chain lengths consisting of $<9 \mathrm{~N}$-acetylneuraminic acid (Neu5Ac) residues [38-40]. The retention time of specific sialic acid chains was determined by mildly labeling $10 \mathrm{mg}$ colominic acid with 1,2-diamino-4,5-methylenedioxybenzene (DMB) (Dojindo, Kumamoto, Japan) under the following conditions: A total of $10 \mathrm{mg}$ colominic acid was dissolved in $200 \mu \mathrm{L}$ DMB reaction buffer (9 mM sodium hydrosulfite, $0.5 \mathrm{M} \beta$-mercaptoethanol, $20 \mathrm{mM}$ trifluoroacetic acid (TFA), and $1.35 \mathrm{M}$ $\mathrm{DMB}$ ) and $200 \mu \mathrm{L}$ MilliQ water, incubated overnight at $11^{\circ} \mathrm{C}$, and stopped by the addition of $100 \mu \mathrm{L}$ 
$1 \mathrm{M} \mathrm{NaOH}[39,41-43]$. The different chain lengths were separated with a DNAPac PAc-100 column $(22 \mathrm{~mm} \times 250 \mathrm{~mm} ; 13 \mu \mathrm{m}$; Thermo Fisher Scientific, Waltham, MA, USA) using HPLC system (Smartline System, Knauer, Berlin, Germany). MilliQ water (E1) and $2 \mathrm{M}$ ammonium acetate buffer (E2) were used as eluents at a flow rate of $2.5 \mathrm{~mL} \mathrm{~min}^{-1}$. The following gradient was used for the separation, $0 \mathrm{~min}=0 \%(v / v) \mathrm{E} 2,20 \mathrm{~min}=26 \%(v / v) \mathrm{E} 2,30 \mathrm{~min}=34 \%(v / v) \mathrm{E} 2,45 \mathrm{~min}=38 \%(v / v) \mathrm{E} 2,85 \mathrm{~min}=88 \%$ $(v / v) \mathrm{E} 2,110 \mathrm{~min}=100 \%(v / v) \mathrm{E} 2$, and $141 \mathrm{~min}=0 \%(v / v)$ E2. DMB-labeled sialic acid chains were detected using a fluorescence detector at $372 \mathrm{~nm}$ for excitation and $456 \mathrm{~nm}$ for emission. In order to proof the degree of polymerization, aliquots of dried samples were mildly DMB labeled, as described above. Sample separation took place on an analytical DNAPac PAc-100 column $(4 \mathrm{~mm} \times 250 \mathrm{~mm}$; $13 \mu \mathrm{m}$; Thermo Fisher Scientific). MilliQ water (E1) and $2 \mathrm{M}$ ammonium acetate buffer (E2) were used as eluents at a flow rate of $1 \mathrm{~mL} \mathrm{~min}^{-1}$ using the following gradient, $0 \mathrm{~min}=100 \%(v / v) \mathrm{E} 1,5 \mathrm{~min}=$ $100 \%(v / v) \mathrm{E} 1,15 \mathrm{~min}=92 \%(v / v) \mathrm{E} 1,20 \mathrm{~min}=89 \%(v / v) \mathrm{E} 1,30 \mathrm{~min}=86 \%(v / v) \mathrm{E} 1,55 \mathrm{~min}=84 \%(v / v)$ $\mathrm{E} 1,100 \mathrm{~min}=80 \%(v / v) \mathrm{E} 1$, and $130 \mathrm{~min}=77 \%(v / v) \mathrm{E} 1$.

\subsection{Quantification of Sialic Acids}

To quantify the amount of N-acetylneuraminic acid, sample aliquots were hydrolyzed with $0.2 \mathrm{~N}$ TFA for $4 \mathrm{~h}$ at $80^{\circ} \mathrm{C}$. Dried samples, as well as appropriate standards, were then DMB-labeled under the following conditions: $40 \mu \mathrm{L} \mathrm{DMB}$ reagent $+40 \mu \mathrm{L}$ MilliQ water, $2 \mathrm{~h}, 55^{\circ} \mathrm{C}, 350 \mathrm{rpm}$. The labeling was stopped by the addition of $20 \mu \mathrm{L} 0.2 \mathrm{M} \mathrm{NaOH}$ [44,45]. The quantification was performed with a LiCroCart 250-2 Merck and a SuperSpher 100 RP-C18 column, as described previously [44-47].

\subsection{Coupling of Sialic Acids on Latex Beads}

The separated sialic acid chains, as well as Neu5Ac (sialic acid monomers; monoSia) (Carbosynth, Compton, UK), were used for coupling reaction. Aliphatic amine latex particles $(1 \% w / v, 0.1 \mu \mathrm{m}$; Thermo Fisher Scientific) were washed twice prior usage. A total of $150 \mu \mathrm{L}$ latex particles were resuspended in $123 \mu \mathrm{L}$ PBS and homogenization was performed by using ultrasonic. A total of $200 \mu \mathrm{g}$ of dried sugars were dissolved in $25 \mu \mathrm{L}$ PBS and then added to the latex particles. A total of $1.5 \mu \mathrm{L} 5 \mathrm{M}$ $\mathrm{NaCNBH}_{3}$ was added and the coupling reaction took place for $2 \mathrm{~h}$ at $65{ }^{\circ} \mathrm{C}$ and $250 \mathrm{rpm}$. After this, sialic acid-coupled particles were washed twice and resuspended in $100 \mu \mathrm{L}$ PBS. An aliquot was taken to quantify the coupling reaction, as described in the previous chapter. The used nanoparticles showed no cytotoxic characteristics as tested previously in [40]. Regarding the stability of the sialylated particles, it should be noted that the sialylation status is reduced by $30 \%$ when stored at $8{ }^{\circ} \mathrm{C}$ for one month, resulting in a decreased activity.

\subsection{Isolation of Human Neutrophils}

Human neutrophils were isolated as described previously by Saffarzadeh et al. [48]. Therefore, a density gradient using a Histopaque-1077 and a Histopaque- 1119 was applied at $37^{\circ} \mathrm{C}$ and $700 \times \mathrm{g}$ for $30 \mathrm{~min}$. The neutrophil containing layer was washed with PBS. After erylysis (lysis buffer: $\mathrm{pH} 7.5$; $0.15 \mathrm{M} \mathrm{NH}_{4} \mathrm{Cl}, 0.1 \mathrm{mM}$ EDTA, $1 \mathrm{mM} \mathrm{KHCO}_{3}$ ) cells were washed with PBS. The erylysis was performed two times. As a final step, the received pellet was washed and resuspended in RPMI 1640 (Thermo Fisher Scientific) with 1\% penicillin/streptomycin (PenStrep; Thermo Fisher Scientific) and 1\% fetal bovine serum (FBS; Thermo Fisher Scientific). A total of 30,000 cells/well were dissolved in RPMI 1640 with $1 \%$ PenStrep, and $1 \%$ FBS and incubated $1 \mathrm{~h}$ at $37^{\circ} \mathrm{C}$ and $5 \% \mathrm{CO}_{2}$ before the NETs were induced.

\subsection{NETosis Stimulation and Inhibition Assay}

The stimulation of neutrophils with $20 \mathrm{nM}$ PMA took place in Poly-L-Lysine coated 12-well chamber slides for $2 \mathrm{~h} / 4 \mathrm{~h}$ at $37^{\circ} \mathrm{C}$ and $5 \% \mathrm{CO}_{2}$. To inhibit NETosis cells were incubated with PMA and a final concentration of $10 \mu \mathrm{g} \mathrm{mL}^{-1}$ sialic acid was coupled on latex particles. Coincubations of $\alpha 2,8$-sialylated particles with $30 \mu \mathrm{g} \mathrm{mL}^{-1}$ free sialic acid chains of an inherent chain length were performed under equal conditions. 


\subsection{Immunofluorescence Staining}

After $2 \mathrm{~h}$ or $4 \mathrm{~h}$ of PMA stimulation cells were fixed with $4 \%$ paraformaldehyde (PFA) for $30 \mathrm{~min}$ at $4{ }^{\circ} \mathrm{C}$. After washing, cells were incubated with $0.5 \%$ Triton $\mathrm{X}-100$ for $1 \mathrm{~min}$, followed by three further washing steps. Blocking was performed for $30 \mathrm{~min}$ at $37^{\circ} \mathrm{C}$ with $2 \%$ IgG free bovine serum albumin (BSA) (Carl Roth, Karlsruhe, Germany) and anti-Neutrophil Elastase (Abcam, Cambridge, UK) was incubated overnight at $4{ }^{\circ} \mathrm{C}$. After further washing steps, the secondary antibody (FITC anti-rabbit, $1 \mathrm{~h}$, room temperature (RT)) was added before the nuclei staining with 4',6-Diamidin-2-phenylindol (DAPI) was done (Carl Roth, $1 \mu \mathrm{g} \mathrm{mL}^{-1}$ ). Fixation was performed with $2 \%$ PFA for 20 min at RT. Samples were then mounted and analyzed using fluorescence microscopy (Carl Zeiss confocal laser scanning microscope LSM 800). The determination of the NET area per cell was based on the release of decondensed DNA fibers during NETosis (DAPI staining) and was performed using Cellprofiler 2.2.0. Three pictures were randomly taken of each biological sample.

\subsection{Measuring of the Production of Reactive Oxygen Species via Dihydrorhodamine 123 (DHR)}

Since the production of reactive oxygen species reaches its maximum after 30 min of PMA incubation [49], 35,000 cells/well were seeded and DHR (Thermo Fisher Scientific) was coincubated with PMA with a final concentration of $1.445 \mu \mathrm{M}$ diluted in RPMI 1640, 1\% FBS, and 1\% PenStrep for $30 \mathrm{~min}$ at $37^{\circ} \mathrm{C}$ and $5 \%$ carbon dioxide. Measurement was performed with a Gallios, Beckman Coulter, at an excitation of $488 \mathrm{~nm}$ and with the emission at $525 \mathrm{~nm} \pm 25 \mathrm{~nm}$ (argon laser).

\subsection{Determination of the Membrane Potential with Bis-(1,3-Dibutylbarbituric Acid)trimethine Oxonol $\left(\mathrm{DiBAC}_{4}\right)$}

The determination of the membrane potential was performed with DiBAC $_{4}$. (Thermo Fisher Scientific). Therefore, 35,000 cells/well were seeded and NETosis was induced with 20 nM PMA for $3.5 \mathrm{~h}$ and cells were further incubated $30 \mathrm{~min}$ with $250 \mathrm{nM} \mathrm{DiBAC}$. Measuring took place with a Gallios, Beckman Coulter, at an excitation of $488 \mathrm{~nm}$ and with the emission at $525 \mathrm{~nm} \pm 25 \mathrm{~nm}$ (argon laser), as described previously by Löhrke et al. [50].

\subsection{NETose-Microscopy of Living Cells}

After the isolation of human neutrophils, 50,000 cells/well were seeded in a Poly-L-Lysine -coated 12-well chamber slide. To de-stress cells from the isolation procedure, the following step was an incubation in RPMI 1640 for $1 \mathrm{~h}$ at $37^{\circ} \mathrm{C}$ and $5 \%$ carbon dioxide. Afterwards, the cells were washed twice with RPMI 1640 and stained with $1 \mu \mathrm{g} \mathrm{mL}{ }^{-1}$ DAPI (Carl Roth) for 30 min before a further washing step was done. To stain the membrane, Deep Red Cell Membrane Stain (1:1000; Thermo Fisher Scientific) was added 15 min before NETosis induction, with 50 nM PMA. Pictures were taken at an interval of 2 per min.

\subsection{Determination of Membrane Integrity via Propidium Iodide (PI) Staining}

Membrane integrity was analyzed using PI (Miltenyi Biotec, Bergisch Gladbach, Germany; Annexin V-FITC Kit) in a final concentration of $1 \mu \mathrm{g} \mathrm{mL} \mathrm{m}^{-1}$. After removing PI, nuclei were stained with Hoechst (Sigma Aldrich, St. Louis, MO, USA) in a final concentration of $1 \mu \mathrm{g} \mathrm{mL}{ }^{-1}$. Cells were directly analyzed using fluorescence microscopy (Carl Zeiss confocal laser scanning microscope LSM 800). Three pictures were randomly taken from three independently performed experiments. The total cell number and PI positive cells were counted.

\subsection{Statistical Analysis}

Data sets were analyzed with Graph Pad Prism 7.0 software using ANOVA and a multiple-comparison Tukey test or a $t$-test with Welch's correction, when the calculated values passed the Shapiro-Wilk normality test. Otherwise, the Kruskal-Wallis test in combination with 
Dunn's test for multiple comparisons was applied. Differences were considered statistically significant at $p \leq 0.05$. Statistically significant differences are given the labels ${ }^{*} p \leq 0.05 ;{ }^{* *} p \leq 0.01 ;{ }^{* *} p \leq 0.001$; and ${ }^{* * *} p \leq 0.0001$.

\section{Results}

\subsection{2,8-Sialylated Particles Decrease the Production of Reactive Oxygen Species and Membrane Depolarization}

NADPH oxidase represents a key enzyme in the signaling cascade during the formation of NET induced by PMA [51]. To test whether nanoparticles containing $\alpha 2,8$-linked sialic acid chains modulate the activation of neutrophils, ROS production was analyzed. To quantify ROS, DHR was used. In the presence of ROS, DHR is oxidized to cationic rhodamine 123, which exhibits green fluorescence. As shown in Figure 1A, in comparison to the neutrophils treated with PMA, unstimulated neutrophils assemble approximately $98 \%$ less ROS. When nanoparticles with sialic acid monomers were applied during the PMA stimulation, no effect on the PMA-induced ROS generation was observed. In contrast, the $\alpha 2,8$-sialylated nanoparticles statistically significantly decrease the ROS production that had been initiated by PMA. However, the production of ROS could not be completely abolished. Thus, chemically coupled $\alpha 2,8$-linked sialic acid chains seem to influence the activation of neutrophils.
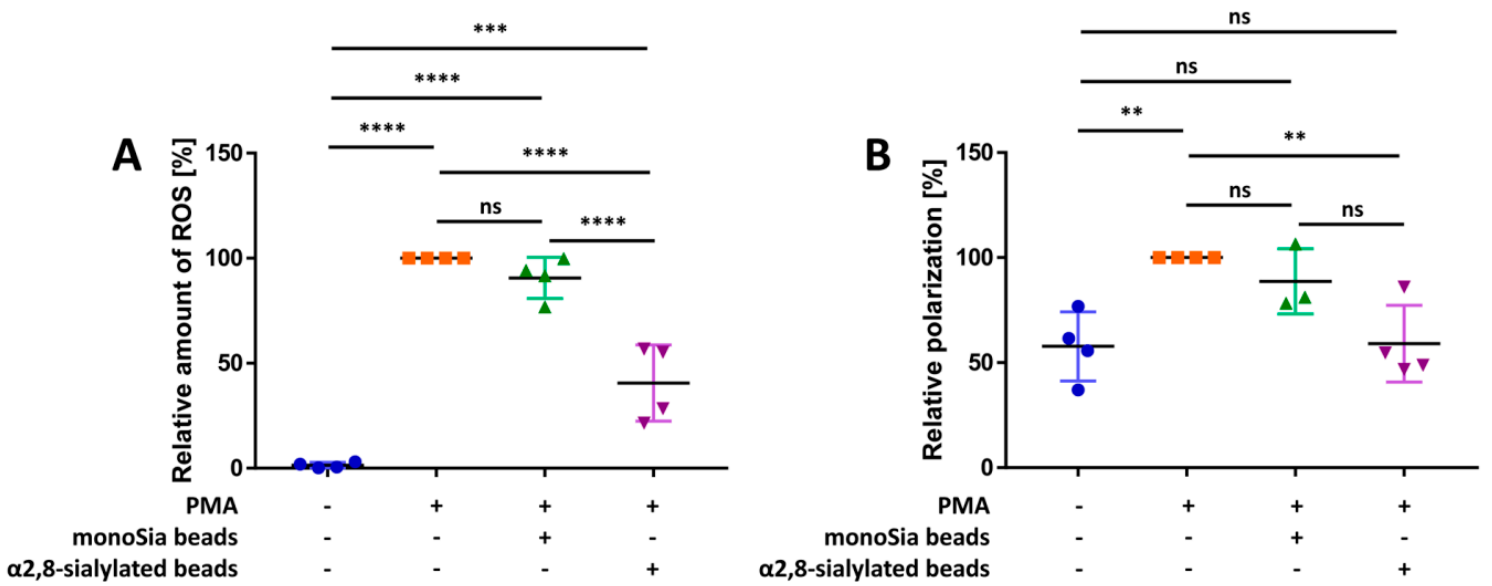

Figure 1. $\alpha 2,8$-sialylated particles reduce the production of ROS and the depolarization of the membrane when neutrophils are stimulated with PMA. (A) Scatter plot of the relative amount of ROS (\%) produced after $30 \mathrm{~min}$ of stimulation with PMA. The determination of the relative amount of ROS (\%) was performed using DHR. The values for PMA-treated cells were set to $100 \%$. Four independent experiments were performed. (B) Scatter plot of the polarization status of the membrane. Determination of membrane depolarization was performed using DiBAC 4 . The emitted fluorescence of the PMA-induced cells was set to $100 \%$. Mean values $(n \geq 3)$ and standard deviations are displayed in the diagrams. ANOVA and a multiple-comparison Tukey test were applied. Statistically significant differences are given as follows: ns, not significant, ${ }^{* *} p \leq 0.01$; ${ }^{* * *} p \leq 0.001$; and ${ }^{* * *}$ $p \leq 0.0001$.

The occurrence of membrane depolarization after activation of the NADPH oxidase complex was described in the 1980s [52-54]. Experiments focused on inhibition of NADPH oxidase complex-induced electron transport showed that the inhibition of electron transport leads to attenuated membrane depolarization [54]. In line with these experiments, neutrophils of patients with chronic granulomatous disease (CGD) showed no membrane depolarization after PMA stimulation, as this disease is characterized by an impaired NADPH oxidase complex $[52,55,56]$. Since $\alpha 2,8$-sialylated nanoparticles inhibit ROS production, we also examined whether membrane depolarization is influenced. To this end, the polarization status of the cells was determined with $\mathrm{DiBAC}_{4}$, a substance that can enter depolarized cells. Here, $\mathrm{DiBAC}_{4}$ can bind intracellular proteins exhibiting enhanced fluorescence and a 
red spectral shift. In Figure 1B, it is apparent that the stimulation of neutrophils with PMA results in cell membrane depolarization. Statistically significant differences between non-treated and stimulated cells were detected, which could not be influenced by monosialylated nanoparticles. However, in line with the ROS experiments, $\alpha 2,8$-sialylated nanoparticles inhibited membrane depolarization considerably.

In sum, the outlined results of the cell assays suggested that the essential steps during PMA stimulation, which trigger the formation of NET, are impaired by $\alpha 2,8$-sialylated nanoparticles.

\subsection{The Swelling of Neutrophil Nuclei Is Not Influenced by $\alpha 2,8$-Sialylated Nanoparticles}

The formation of ROS is directly linked to the translocation of neutrophil elastase into the nucleus because ROS serves as a substrate for myeloperoxidase. Subsequently, the increase in $\mathrm{HOCl}$ initiates the detachment of neutrophil elastase from the myeloperoxidase/neutrophil elastase complex, enabling the transfer of neutrophil elastase into the nucleus and triggering decondensation of DNA [4,9]. The result is that the nuclei lose their typical segmented structure and swell.

When we compared the nuclear structure of unstimulated neutrophils with that of the activated neutrophils in the presence of $\alpha 2,8$-sialylated nanoparticles, we observed that nearly all nuclei lost their segmented structure and the nuclei were swollen $4 \mathrm{~h}$ after the beginning of the PMA stimulation (Figure 2). Thus, the results suggest that the decondensation of DNA could not be prevented.

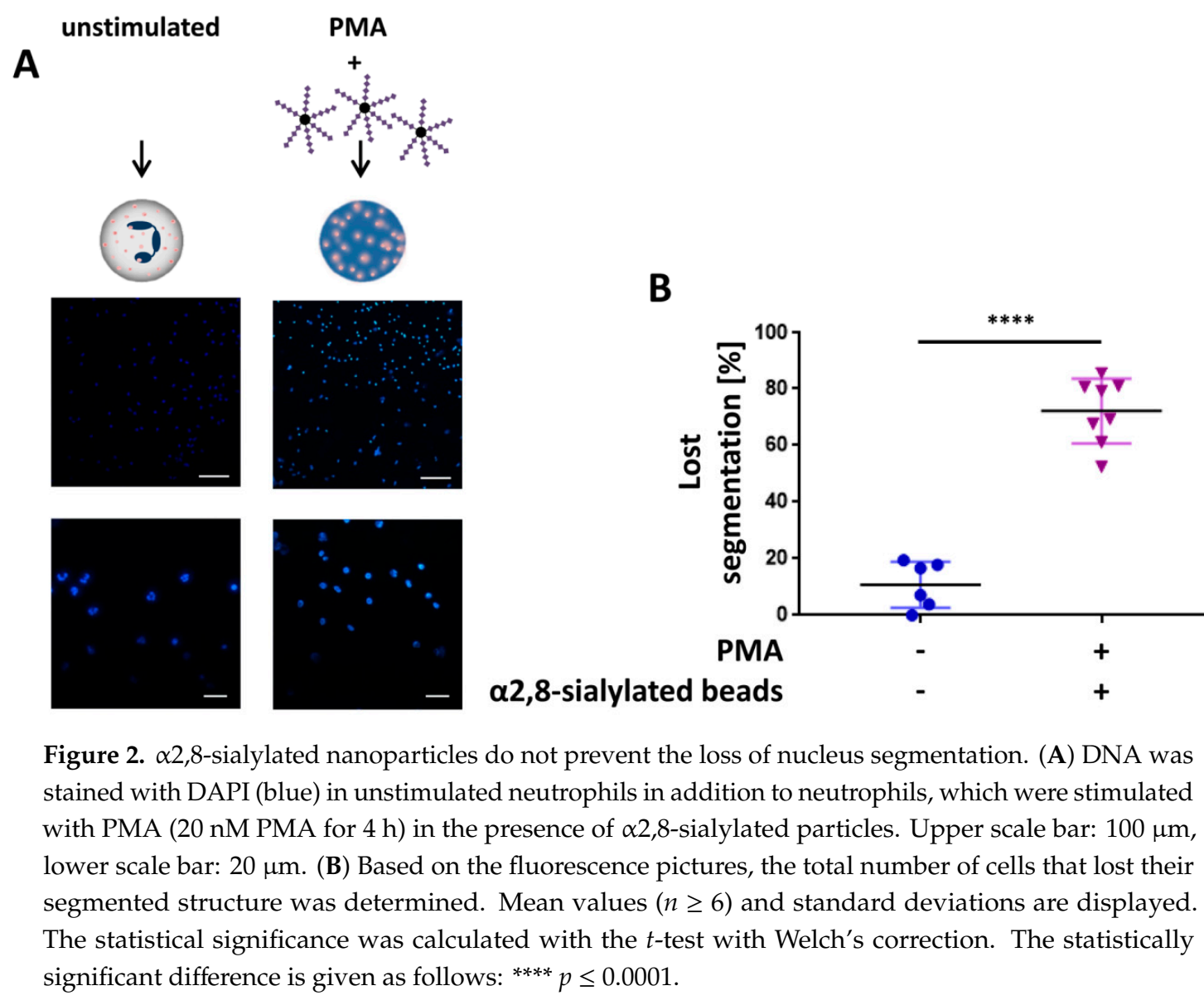

The translocation of neutrophil elastase to the nuclei is an important step during the decondensation of DNA and the formation of NETs [16]. To test whether the localization of neutrophil elastase was also unchanged due to the application of $\alpha 2,8$-sialylated nanoparticles, the enzyme was visualized using a polyclonal $\mathrm{Ab}$ against neutrophil elastase. Based on published data concerning the time point of the translocation of neutrophil elastase into the nucleus, immunofluorescence staining of neutrophil elastases was performed $2 \mathrm{~h}$ after the PMA treatment [16]. 
In contrast to the unstimulated neutrophils, neutrophil elastase was transferred into the nucleus after stimulation (Figure 3). In addition, the segmented structure of the nucleus was resolved. Comparable results were obtained using $\alpha 2,8$-sialylated particles. Thus, the reduction of ROS to approximately $40 \%$, which was induced by $\alpha 2,8$-sialylated nanoparticles, does not prevent the transformation of the nuclei.

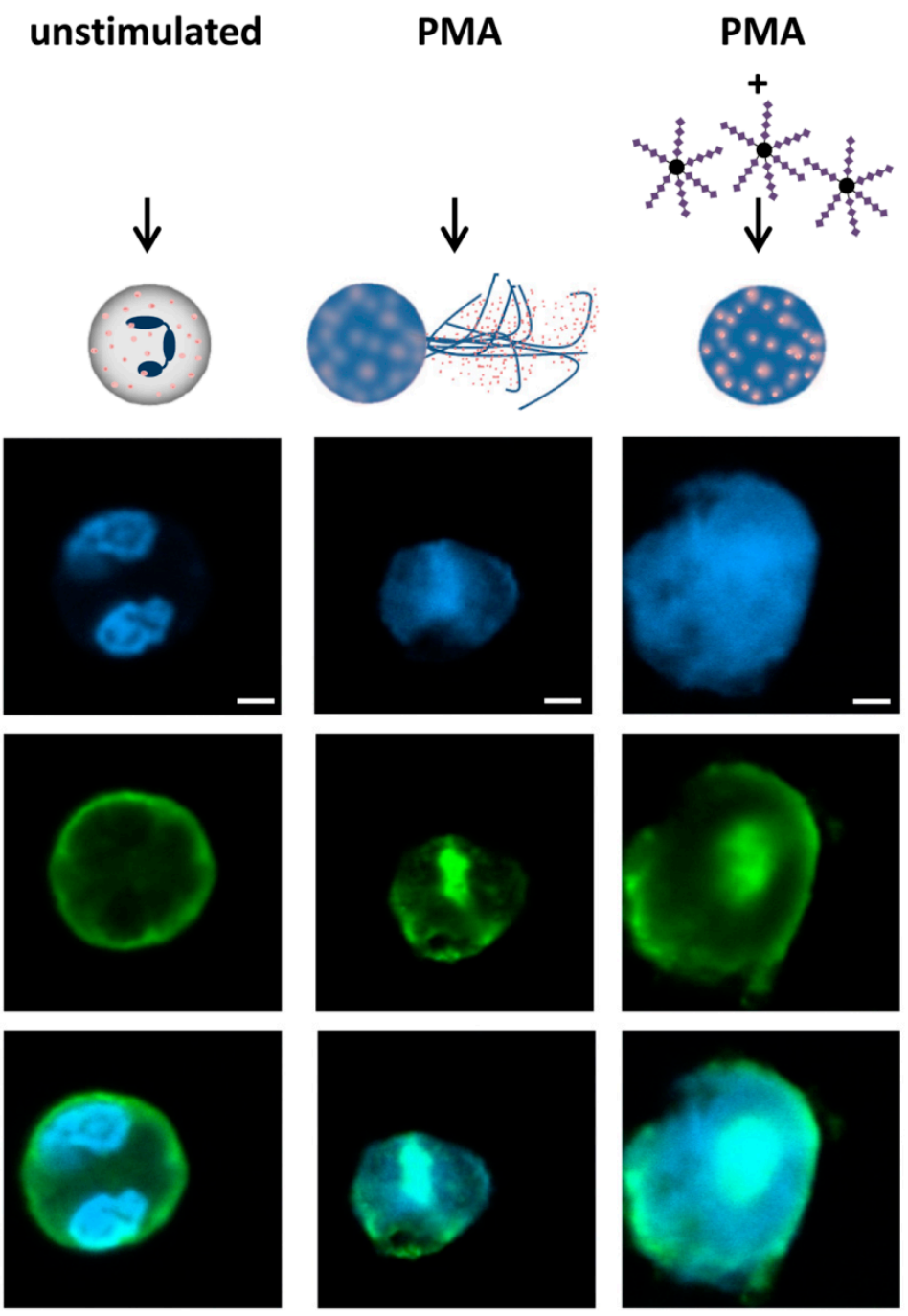

Figure 3. Neutrophil elastase also enters the nucleus during the application of $\alpha 2,8$-sialylated nanoparticles. Cells were incubated with $20 \mathrm{nM}$ PMA for $2 \mathrm{~h}$ and were stained with a polyclonal antibody against neutrophil elastase (FITC; green). DNA was visualized using DAPI (blue). Scale bar: $2 \mu \mathrm{m}$.

\section{3. $\alpha 2,8$-Sialylated Particles Inhibit the Release of NET}

In addition, the release of NET was examined. The stimulation of NETosis leads to the formation of the DNA meshwork, which can be visualized with DAPI. As shown in Figure 4A,B, $4 \mathrm{~h}$ after PMA stimulation, the expected NET filaments are formed. In contrast, the unstimulated neutrophils retained their shape, including their segmented nuclei. However, the application of $\alpha 2,8$-sialylated nanoparticles prevented NET release although the nuclei were swollen. The calculation of the NET area shows that NET expansion was statistically significantly reduced.

The same experimental test setup was also performed with monosialylated beads, which showed no impact on the activation by PMA (Figure 5). In addition, experiments were performed to investigate whether free sialic acid chains have the same effect or whether sialic acid chains have to be attached to 
a linker to inhibit the release of NETs. To this end, we used free sialic acid chains together with the $\alpha 2,8$-sialylated beads. Again, $\alpha 2,8$-sialylated nanoparticles had the capability to prevent NET release (Figure 6). However, this effect was inhibited by free sialic acid chains. Thus, a linker molecule is necessary to inhibit the release of NETs.

\section{A unstimulated}

\section{PMA}
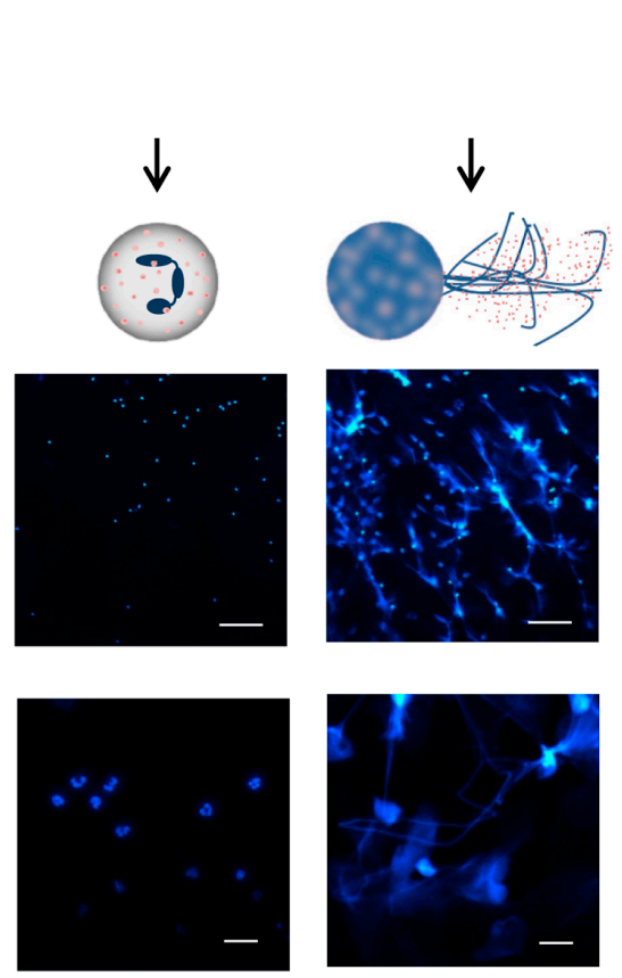

B

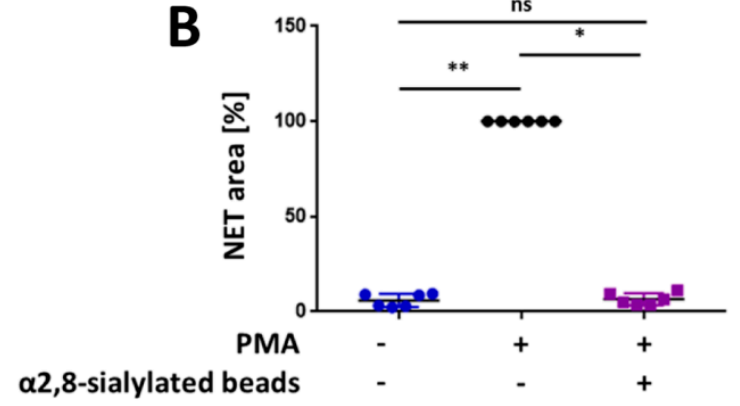

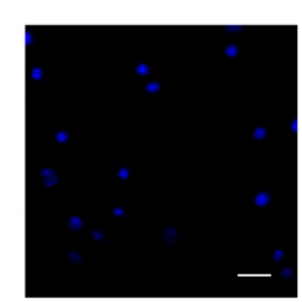

PMA
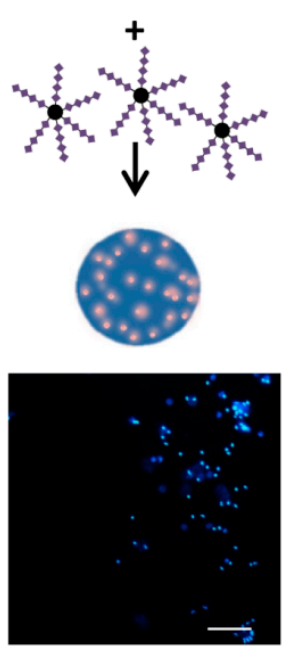

Figure 4. $\alpha 2,8$-sialylated particles inhibit NET release. (A) Fluorescence staining (DAPI; blue) of neutrophils without any stimulation of neutrophils, stimulated with $20 \mathrm{nM}$ PMA for $4 \mathrm{~h}$, and of neutrophils stimulated with 20 nM PMA coincubated with $\alpha 2,8$-sialylated particles for $4 \mathrm{~h}$. Upper scale bar: $100 \mu \mathrm{m}$, lower scale bar: $20 \mu \mathrm{m}$. (B) Analysis of the NET area (\%). The analysis was performed using Cell Profiler 2.2.0. The NETosis area (\%) was calculated by determining the blue fluorescent areas (DAPI). PMA inducement was set to $100 \%$. Mean values $(n=6)$ and standard deviations are displayed. The Kruskal-Wallis test and Dunn's test for multiple comparisons were applied. Statistically significant differences are given as follows: ns, not significant, ${ }^{*} p \leq 0.05$ and ${ }^{* *} p \leq 0.01$. 

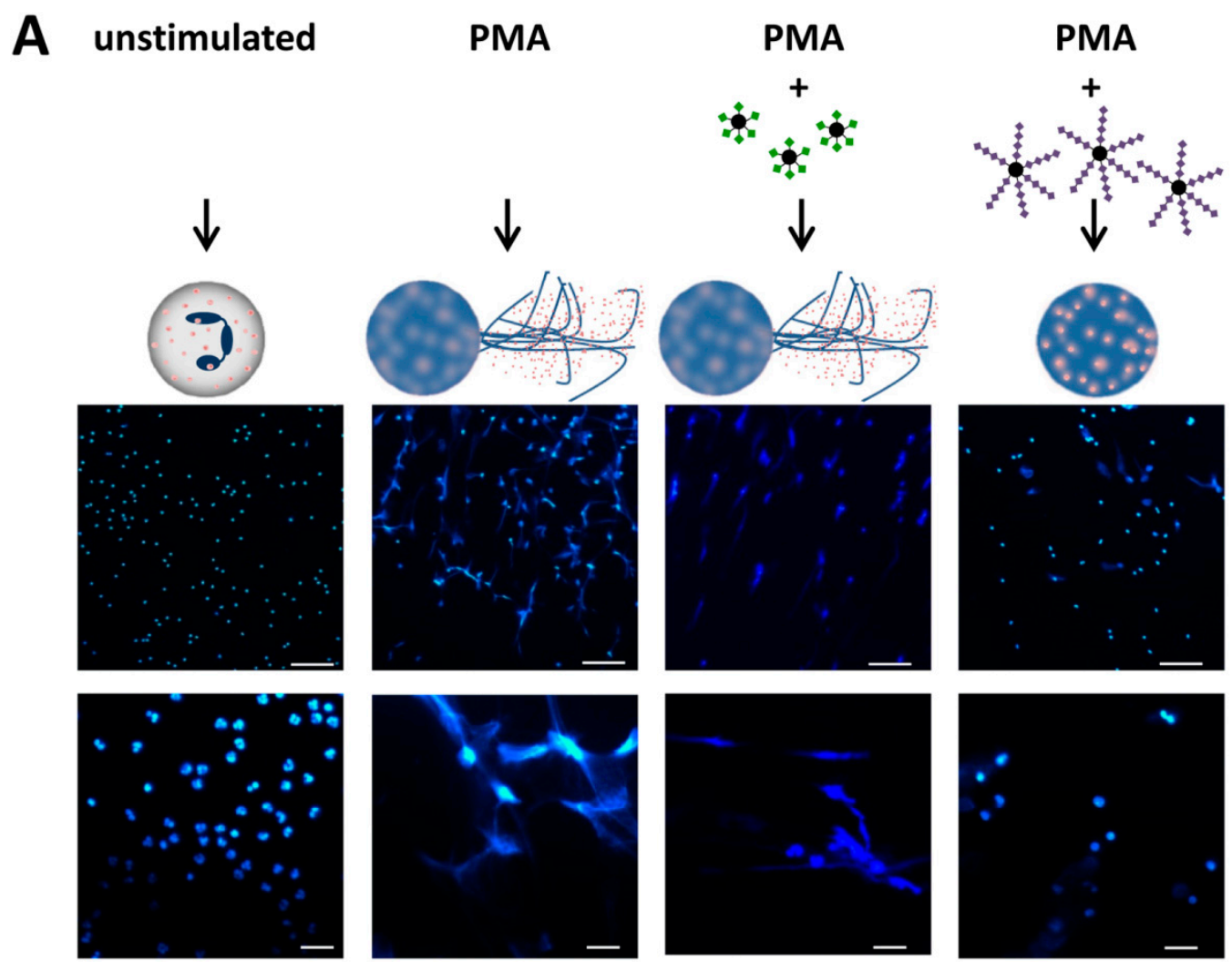

B
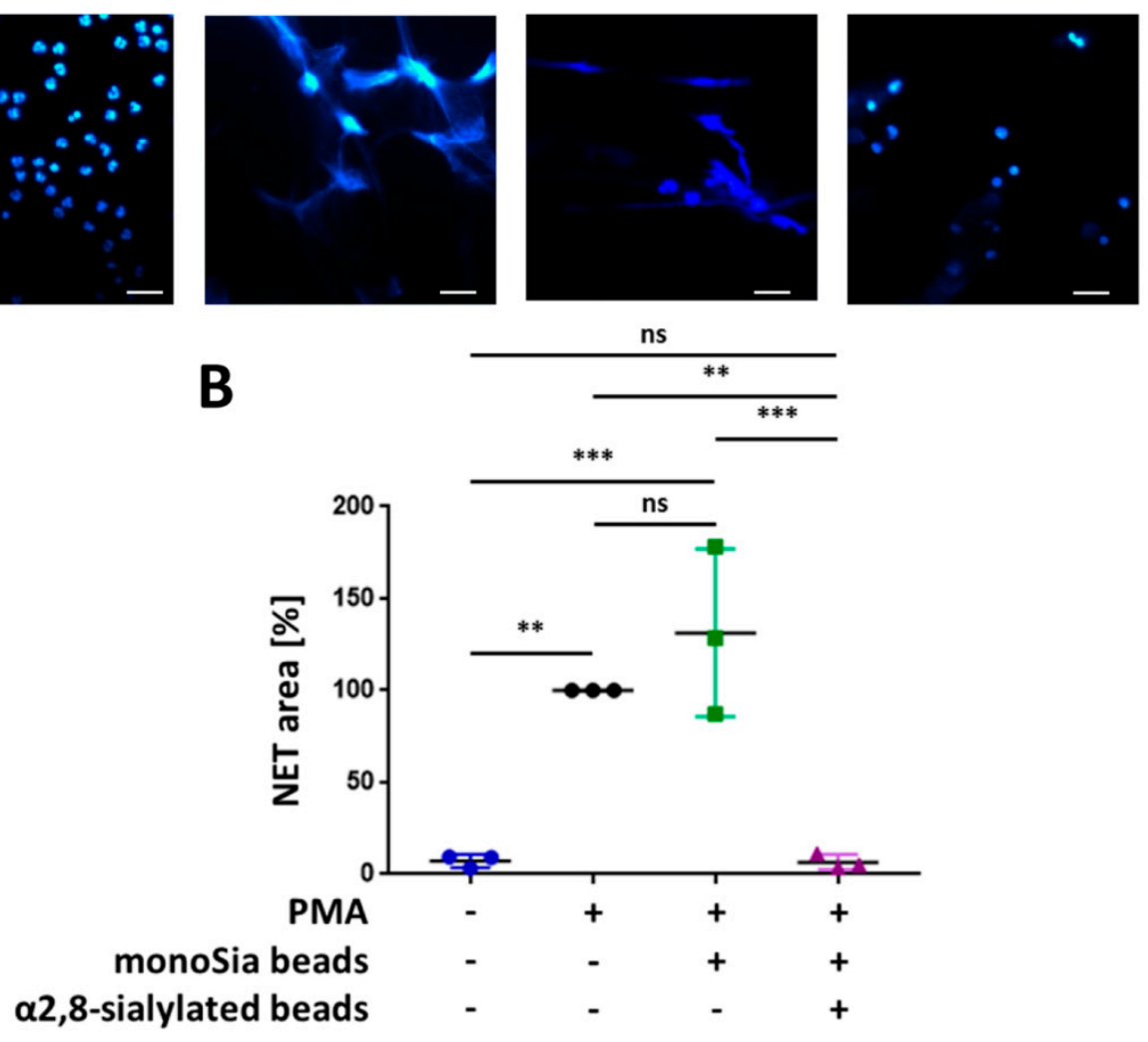

Figure 5. $\alpha 2,8$-sialylated particles inhibit NET release. (A) Fluorescence staining (DAPI; blue) of neutrophils without any stimulation of neutrophils, stimulated with $20 \mathrm{nM}$ PMA for $4 \mathrm{~h}$, and of neutrophils stimulated with $20 \mathrm{nM}$ PMA coincubated with monosialylated particles or $\alpha 2,8$-sialylated particles for $4 \mathrm{~h}$. Upper scale bar: $100 \mu \mathrm{m}$, lower scale bar: $20 \mu \mathrm{m}$. (B) Analysis of the NET area (\%). The analysis was performed using Cell Profiler 2.2.0. The NETosis area (\%) was calculated by determining the blue fluorescent areas (DAPI). PMA inducement was set to $100 \%$. Mean values $(n=3)$ and standard deviations are displayed. ANOVA and multiple comparison Tukey test were applied. Significant differences are given as follows: ns, not significant, ${ }^{* *} p \leq 0.01$ and ${ }^{* * *} p \leq 0.001$. 


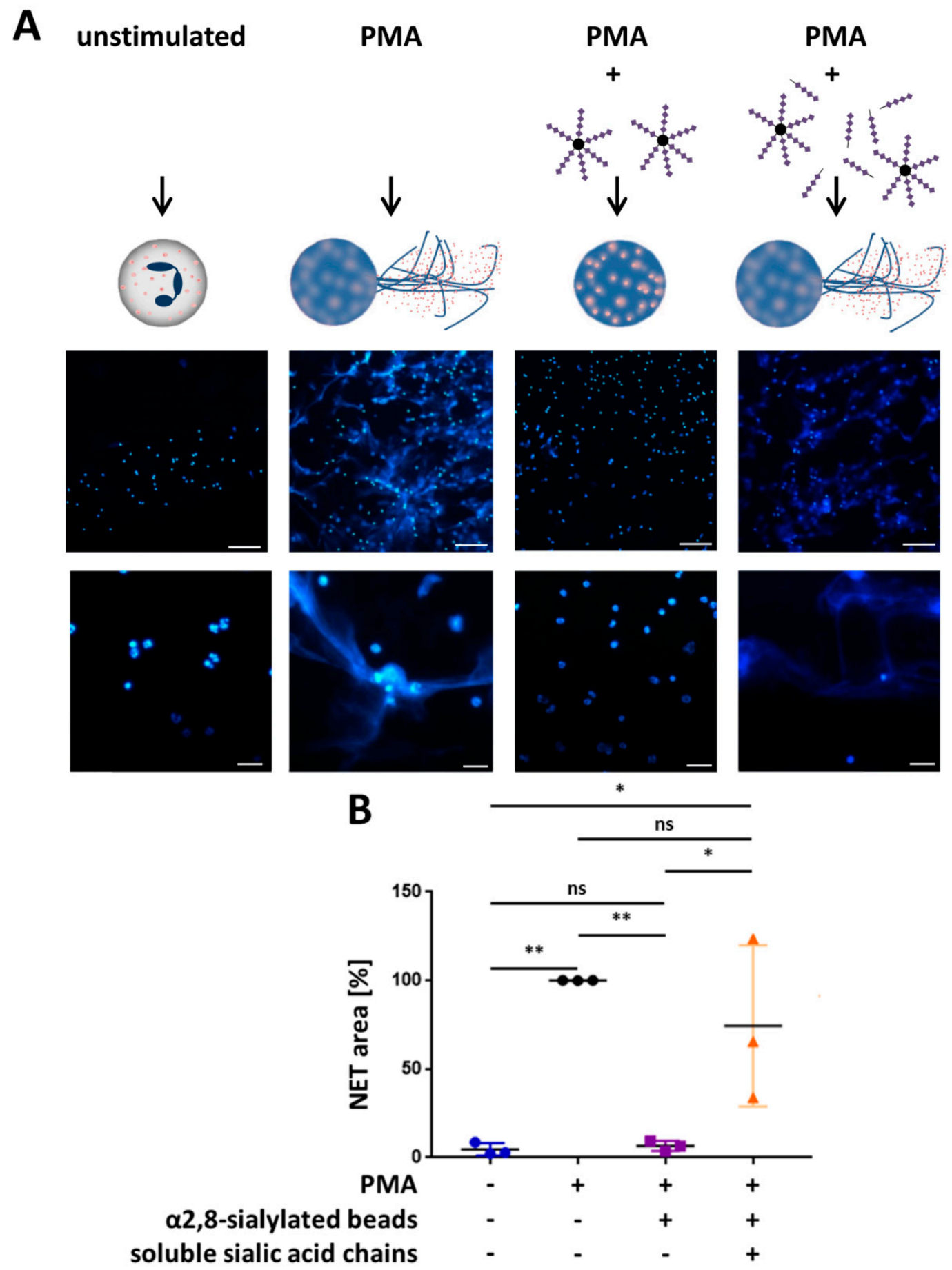

Figure 6. Free sialic acid chains prevent the outlined inhibitory effects of $\alpha 2,8$-sialylated particles. (A) Fluorescence staining (DAPI; blue) of isolated human neutrophils stimulated with 20 nM PMA and coincubated with $\alpha 2,8$-sialylated particles or free sialic acid chains in combination with $\alpha 2,8$-sialylated nanoparticles. Upper scale bar: $100 \mu \mathrm{m}$, lower scale bar: $20 \mu \mathrm{m}$. (B) Analysis of the NET area (\%). Analysis was performed on three different experimental approaches using Cell Profiler 2.2.0. NETosis area (\%) was calculated by determining the blue fluorescent areas (DAPI). PMA stimulation was set to $100 \%$. Mean values and standard deviations are displayed in the diagrams. ANOVA and multiple comparison Tukey test were applied. Significant differences are given as follows: ns, not significant, ${ }^{*} p \leq 0.05$ and ${ }^{* *} p \leq 0.01$. 


\section{4. $\alpha 2,8$-Sialylated Particles Prevent Cell Membrane Perforation}

For the release of NETs, cell membrane rupture is necessary [9]. Using Deep Red Cell Membrane Staining, it is possible to visualize the cellular membrane during NETosis and its explosive bursts to release the DNA network (illustrated in Figure 7 and Supplemental 1; video). The resulting hole allowed the release of intracellular substances and the penetration of molecules into the cell. Interestingly, the intensity of the membrane staining became stronger during the alteration of the nuclear structure, indicating that the membrane properties of the neutrophils had changed before the release of NETs.

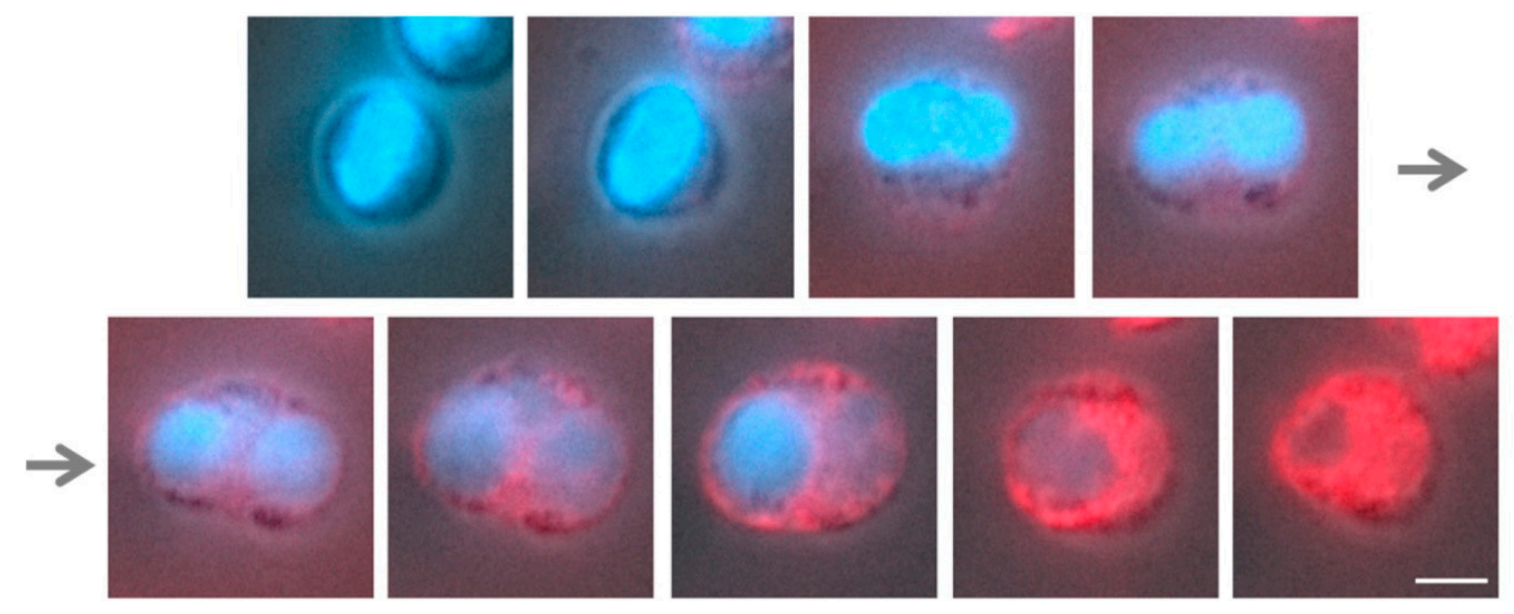

Figure 7. Release of NETs. NETosis stimulation was performed with $50 \mathrm{nM}$ PMA. At the very beginning of PMA induction, a healthy cell with an intact nucleus is visible. Then DNA decondensation takes place, followed by disintegration of the nuclear membrane and a fusion of DNA with the released cytoplasmic proteins. Thus, at this time point, the cell dimension expands, leading to a rupture of the outer membrane, along with the release of the DNA-protein mixture into the fluid surrounding the cell. The empty cell membrane remains behind. The cell membrane (red) was stained with Deep Red and DNA (blue) with DAPI. Scale bar: $5 \mu \mathrm{m}$.

In order to test whether the outer membranes were still intact we used PI, a substance that can pass only perforated, not intact, biomembranes. Once PI enters the cell, it interacts with DNA, resulting in a red fluorescent staining. The calculation was performed by counting the total number of cells compared to the number of PI-positive cells. The results indicate that, compared to untreated neutrophils, PMA led to an increasing number of perforated cells (Figure 8 ). Similar results were obtained when monosialylated beads were added. However, the application of $\alpha 2,8$-sialylated beads resulted in a significantly reduced number of PI-positive cells, demonstrating that $\alpha 2,8$-sialylated beads inhibit the perforation of the biomembrane, and thus, the release NET. 


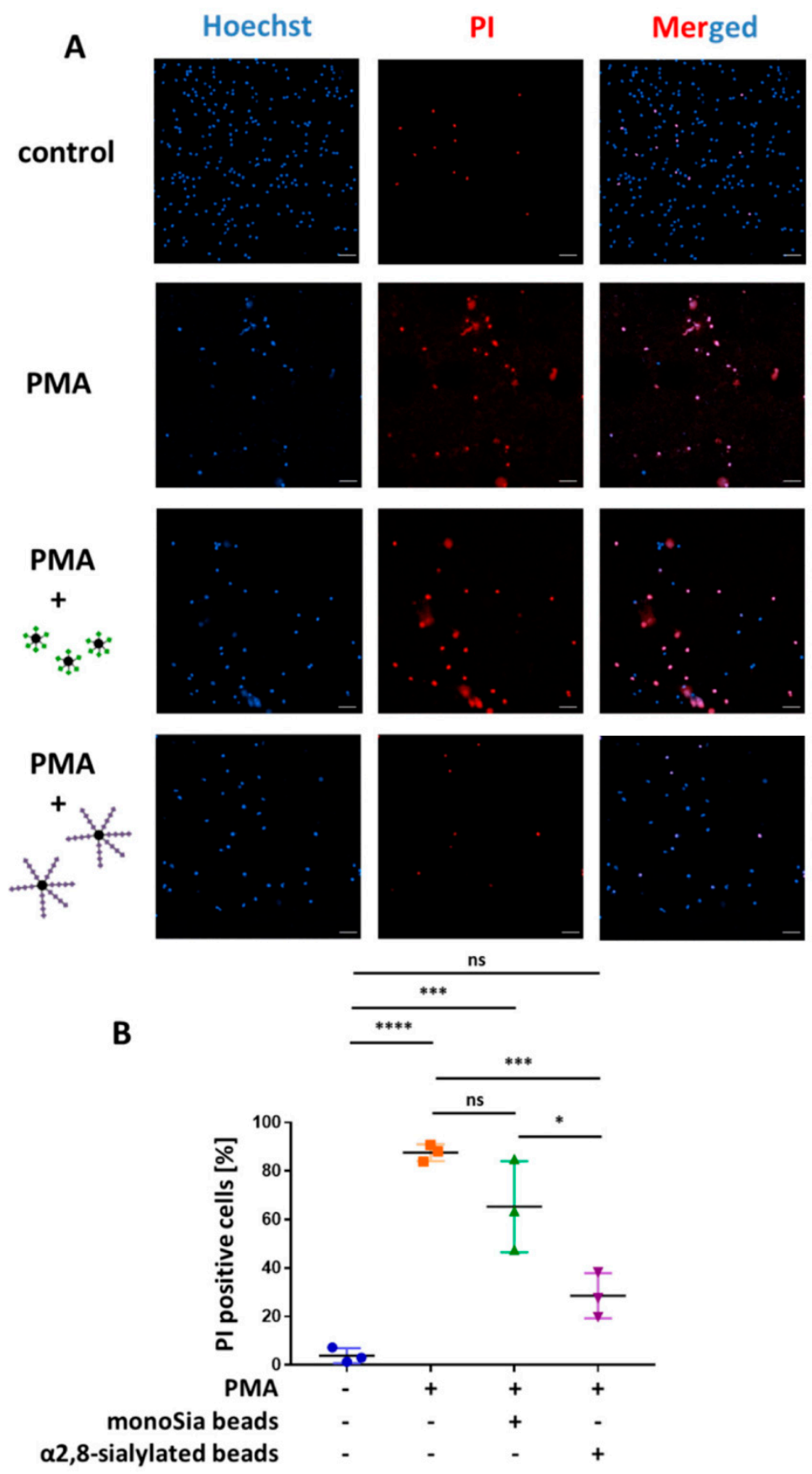

Figure 8. Coincubation of PMA-stimulated neutrophils with $\alpha 2,8$-sialylated particles significantly decreases the number of PI-positive cells. (A) Isolated neutrophils stimulated with $20 \mathrm{nM}$ PMA and isolated neutrophils stimulated with $20 \mathrm{nM}$ PMA coincubated with $\alpha 2,8$-sialylated particles or monosialylated particles were stained with PI (red) and Hoechst (blue) to determine membrane permeability. Unstimulated isolated neutrophils served as a control. Scale bars: $50 \mu \mathrm{m}$. (B) Based on the fluorescence images the total number of cells was determined and was set in relation to the number of PI-positive cells. Mean values $(n=3)$ and standard deviations are displayed in the diagrams. ANOVA and a multiple-comparison Tukey test were applied. Significant differences are given as follows: ns, not significant, ${ }^{*} p \leq 0.05 ;{ }^{* * *} p \leq 0.001$; and ${ }^{* * * *} p \leq 0.0001$.

\section{Discussion}

In 2015, Spence et al. discovered that nanoparticles coated with the murine siglec-E ligand, $\alpha 2,8$-linked sialic acid residues, decrease macrophage-driven inflammation [33]. Based on this 
discovery, we decided to investigate the potential of $\alpha 2,8$-sialylated particles to inhibit the release of NETs. Interestingly, the application of $\alpha 2,8$-sialylated particles decreased the production of ROS in PMA-stimulated neutrophils, while monosialylated particles showed no effect. In line with the reduced ROS, depolarization was also inhibited by these sugar-coated nanoparticles. Since the activation of the NADPH oxidase complex includes PKC and the Raf-MEK-ERK pathway, resulting in the formation of ROS [14,57], and siglecs are known to inhibit the immune response by counteracting kinases via the recruitment of the phosphatases SHP1 and SHP2 [28,30], the involvement of siglecs may trigger these observations. As siglec- 5 is known to prefer $\alpha 2,8$-linked sialic acids, decreased ROS production and depolarization might be the result of the interaction between $\alpha 2,8$-linked chains and siglec- 5 of neutrophils [34-36]. However, the impaired ROS production and depolarization did not prevent swelling of the nuclei. This indirectly indicates that neutrophil elastases still translocate to the nuclei, because neutrophil elastase is necessary for decondensation of DNA and, therefore, for nuclei swelling as described previously [16].

Nevertheless, the release of NETs was retained and the $\alpha 2,8$-sialylated particles prevented the perforation of the outer membrane (Figure 8). Interestingly, a comparable effect was described for lactoferrin [58]. In line with $\alpha 2,8$-sialylated beads, elastase translocates to the nucleus in the presence of lactoferrin and nucleus swelling takes place. In addition, in the case of lactoferrin, the last step, the release of NET is inhibited. Okubo and colleagues observed that lactoferrin accumulates on the surface of neutrophils [58]. They suggested a physical blocking barrier, which is mediated via a "lactoferrin-shell". The first released DNA aggregates with lactoferrin forming a plug, which prevents the release of NETs [58]. As recently shown, polysialic acid (polySia) can interact with lactoferrin and supports the effect of lactoferrin to inhibit NET release [59]. However, whether the membrane was still intact was not tested.

In addition to lactoferrin, $\alpha 2,8$-linked polymers of sialic acids are known to induce membrane interactions, because these polymers can interact with phospholipids [60]. This interaction usually takes place in ordered regions of membranes, such as lipid rafts [61]. The staining of cell membranes with Deep Red during NETosis (Figure 7) suggested that fluid and dynamic processes occur in the biomembrane, which might mediate such an interaction. Thus, we suggest that the membrane is stabilized by the multivalency of $\alpha 2,8$-sialylated nanoparticles, which might act as "cross struts". Furthermore, perhaps an interaction with membrane proteins, such as siglec-5, supports the stabilization of the cell membrane in a comparable fashion. These hypotheses are supported by the observation that free sialic acid chains inhibit the effects of the $\alpha 2,8$-sialylated nanoparticles.

However, in contrast to lactoferrin, $\alpha 2,8$-sialylated beads influence ROS production [58], which is essential for the formation of NETs induced by PMA. The observed inhibition of ROS formation might be the result of an activation of siglec- 5 by the $\alpha 2,8$-sialylated beads. The lower ROS content might additionally reduce the dynamic of the neutrophil burst. Presumably, the combination of these two effects (the "cross struts" effect and lower ROS levels) leads to stabilization of the biomembrane, which prevents the cell membrane from rupturing.

Although the exact mechanism of action has been unknown until now, $\alpha 2,8$-sialylated nanoparticles are a promising option for modulating NETosis during NET-related pathologies. Furthermore, for application as a pharmacological tool, the $\alpha 2,8$-sialylated nanoparticles must be tested in different in vivo models where NETs are the main cause that induces pathology.

Supplementary Materials: The following are available online at http://www.mdpi.com/2079-4991/9/4/610/s1, Supplemental 1: Visualization of NETosis.

Author Contributions: K.F.B., T.V. and A.K. performed the experiments and analyzed in addition to S.P.G. the data. The manuscript was written through contributions of all authors. All authors have given approval to the final version of the manuscript.

Funding: This work was supported by a grant of the Deutsche Forschungsgemeinschaft (GA 1755/1-2). The publication of this article was funded by the Open Access Fund of the Leibniz Institute for Farm Animal Biology (FBN). 
Acknowledgments: The authors thank for the excellent technical help of Gesine Krüger and Christian Plinski. We thank Martina Mühlenhoff for the kind gift of endoN.

Conflicts of Interest: The authors have no conflicts of interest to declare.

\section{References}

1. Kessenbrock, K.; Frohlich, L.; Sixt, M.; Lammermann, T.; Pfister, H.; Bateman, A.; Belaaouaj, A.; Ring, J.; Ollert, M.; Fassler, R.; et al. Proteinase 3 and neutrophil elastase enhance inflammation in mice by inactivating antiinflammatory progranulin. J. Clin. Investig. 2008, 118, 2438-2447. [CrossRef] [PubMed]

2. Lekstrom-Himes, J.A.; Gallin, J.I. Immunodeficiency diseases caused by defects in phagocytes. N. Engl. J. Med. 2000, 343, 1703-1714. [CrossRef]

3. Nathan, C. Neutrophils and immunity: Challenges and opportunities. Nat. Rev. Immunol. 2006, 6, $173-182$. [CrossRef]

4. Nel, J.G.; Theron, A.J.; Pool, R.; Durandt, C.; Tintinger, G.R.; Anderson, R. Neutrophil extracellular traps and their role in health and disease. S. Afr. J. Sci. 2016, 112, 1-9. [CrossRef]

5. Brinkmann, V.; Reichard, U.; Goosmann, C.; Fauler, B.; Uhlemann, Y.; Weiss, D.S.; Weinrauch, Y.; Zychlinsky, A. Neutrophil extracellular traps kill bacteria. Science 2004, 303, 1532-1535. [CrossRef] [PubMed]

6. Nauseef, W.M. How human neutrophils kill and degrade microbes: An integrated view. Immunol. Rev. 2007, 219, 88-102. [CrossRef] [PubMed]

7. Papayannopoulos, V.; Zychlinsky, A. NETs: A new strategy for using old weapons. Trends Immunol. 2009, 30, 513-521. [CrossRef]

8. Urban, C.F.; Ermert, D.; Schmid, M.; Abu-Abed, U.; Goosmann, C.; Nacken, W.; Brinkmann, V.; Jungblut, P.R.; Zychlinsky, A. Neutrophil Extracellular Traps Contain Calprotectin, a Cytosolic Protein Complex Involved in Host Defense against Candida albicans. PLoS Pathog. 2009, 5, e1000639. [CrossRef] [PubMed]

9. Brinkmann, V.; Zychlinsky, A. Neutrophil extracellular traps: Is immunity the second function of chromatin? J. Cell Biol. 2012, 198, 773-783. [CrossRef]

10. Neeli, I.; Dwivedi, N.; Khan, S.; Radic, M. Regulation of Extracellular Chromatin Release from Neutrophils. J. Innate Immun. 2009, 1, 194-201. [CrossRef] [PubMed]

11. Rahman, S.; Gadjeva, M. Does NETosis Contribute to the Bacterial Pathoadaptation in Cystic Fibrosis? Front. Immunol. 2014, 5, 378. [CrossRef] [PubMed]

12. De Bont, C.M.; Koopman, W.J.H.; Boelens, W.C.; Pruijn, G.J.M. Stimulus-dependent chromatin dynamics, citrullination, calcium signalling and ROS production during NET formation. Biochim. Biophys. Acta Mol. Cell Res. 2018, 1865, 1621-1629. [CrossRef]

13. Desai, J.; Mulay, S.; Nakazawa, D.; Anders, H. Matters of life and death. How neutrophils die or survive along NET release and is "NETosis" = necroptosis? Cell. Mol. Life Sci. 2016, 73, 2211-2219. [CrossRef] [PubMed]

14. Dwivedi, N.; Radic, M. Citrullination of autoantigens implicates NETosis in the induction of autoimmunity. Ann. Rheum. Dis. 2014, 73, 483-491. [CrossRef] [PubMed]

15. Brinkmann, V. Neutrophil Extracellular Traps in the Second Decade. J. Innate Immun. 2018, 10, 414-421. [CrossRef] [PubMed]

16. Papayannopoulos, V.; Metzler, K.D.; Hakkim, A.; Zychlinsky, A. Neutrophil elastase and myeloperoxidase regulate the formation of neutrophil extracellular traps. J. Cell Biol. 2010, 191, 677-691. [CrossRef] [PubMed]

17. Brill, A.; Fuchs, T.A.; Savchenko, A.S.; Thomas, G.M.; Martinod, K.; De Meyer, S.F.; Bhandari, A.A.; Wagner, D.D. Neutrophil extracellular traps promote deep vein thrombosis in mice. J. Thromb. Haemost. 2012, 10, 136-144. [CrossRef]

18. Hakkim, A.; Fürnrohr, B.G.; Amann, K.; Laube, B.; Abed, U.A.; Brinkmann, V.; Herrmann, M.; Voll, R.E.; Zychlinsky, A. Impairment of neutrophil extracellular trap degradation is associated with lupus nephritis. Proc. Natl. Acad. Sci. USA 2010, 107, 9813-9818. [CrossRef]

19. Fuchs, T.A.; Brill, A.; Duerschmied, D.; Schatzberg, D.; Monestier, M.; Myers, D.D., Jr.; Wrobleski, S.K.; Wakefield, T.W.; Hartwig, J.H.; Wagner, D.D. Extracellular DNA traps promote thrombosis. Proc. Natl. Acad. Sci. USA 2010, 107, 15880-15885. [CrossRef]

20. Kaplan, M.J. Role of neutrophils in systemic autoimmune diseases. Arthritis Res. Ther. 2013, 15, 219. [CrossRef] 
21. Kessenbrock, K.; Krumbholz, M.; Schonermarck, U.; Back, W.; Gross, W.L.; Werb, Z.; Grone, H.J.; Brinkmann, V.; Jenne, D.E. Netting neutrophils in autoimmune small-vessel vasculitis. Nat. Med. 2009, 15, 623-625. [CrossRef] [PubMed]

22. Von Brühl, M.-L.; Stark, K.; Steinhart, A.; Chandraratne, S.; Konrad, I.; Lorenz, M.; Khandoga, A.; Tirniceriu, A.; Coletti, R.; Köllnberger, M.; et al. Monocytes, neutrophils, and platelets cooperate to initiate and propagate venous thrombosis in mice in vivo. J. Exp. Med. 2012, 209, 819-835. [CrossRef]

23. Hahn, S.; Giaglis, S.; Hoesli, I.; Hasler, P. Neutrophil NETs in reproduction: From infertility to preeclampsia and the possibility of fetal loss. Front. Immunol. 2012, 3, 362. [CrossRef] [PubMed]

24. Varki, A. Biological roles of glycans. Glycobiology 2017, 27, 3-49. [CrossRef] [PubMed]

25. Schauer, R. Sialic acids: Fascinating sugars in higher animals and man. Zoology 2004, 107, 49-64. [CrossRef] [PubMed]

26. Bornhofft, K.F.; Goldammer, T.; Rebl, A.; Galuska, S.P. Siglecs: A journey through the evolution of sialic acid-binding immunoglobulin-type lectins. Dev. Comp. Immunol. 2018, 86, 219-231. [CrossRef]

27. Bochner, B.S.; Zimmermann, N. Role of siglecs and related glycan-binding proteins in immune responses and immunoregulation. J. Allergy Clin. Immunol. 2015, 135, 598-608. [CrossRef] [PubMed]

28. Crocker, P.R.; Paulson, J.C.; Varki, A. Siglecs and their roles in the immune system. Nat. Rev. Immunol. 2007, 7, 255-266. [CrossRef] [PubMed]

29. Varki, A.; Angata, T. Siglecs-The major subfamily of I-type lectins. Glycobiology 2006, 16, 1R-27R. [CrossRef]

30. Avril, T.; Freeman, S.D.; Attrill, H.; Clarke, R.G.; Crocker, P.R. Siglec-5 (CD170) can mediate inhibitory signaling in the absence of immunoreceptor tyrosine-based inhibitory motif phosphorylation. J. Biol. Chem. 2005, 280, 19843-19851. [CrossRef]

31. Lizcano, A.; Secundino, I.; Dohrmann, S.; Corriden, R.; Rohena, C.; Diaz, S.; Ghosh, P.; Deng, L.; Nizet, V.; Varki, A. Erythrocyte sialoglycoproteins engage Siglec-9 on neutrophils to suppress activation. Blood 2017, 129, 3100-3110. [CrossRef] [PubMed]

32. Jandus, C.; Simon, H.U.; von Gunten, S. Targeting siglecs-A novel pharmacological strategy for immunoand glycotherapy. Biochem Pharm. 2011, 82, 323-332. [CrossRef]

33. Spence, S.; Greene, M.K.; Fay, F.; Hams, E.; Saunders, S.P.; Hamid, U.; Fitzgerald, M.; Beck, J.; Bains, B.K.; Smyth, P.; et al. Targeting Siglecs with a sialic acid-decorated nanoparticle abrogates inflammation. Sci. Transl. Med. 2015, 7, 303ra140. [CrossRef]

34. O'Reilly, M.K.; Paulson, J.C. Siglecs as targets for therapy in immune-cell-mediated disease. Trends Pharm. Sci. 2009, 30, 240-248. [CrossRef]

35. Angata, T.; Nycholat, C.M.; Macauley, M.S. Therapeutic Targeting of Siglecs using Antibody- and Glycan-Based Approaches. Trends Pharmacol. Sci. 2015, 36, 645-660. [CrossRef]

36. Macauley, M.S.; Crocker, P.R.; Paulson, J.C. Siglec regulation of immune cell function in disease. Nat. Rev. Immunol. 2014, 14, 653-666. [CrossRef]

37. Stummeyer, K.; Dickmanns, A.; Mühlenhoff, M.; Gerardy-Schahn, R.; Ficner, R. Crystal structure of the polysialic acid-degrading endosialidase of bacteriophage K1F. Nat. Struct. Mol. Biol. 2005, 12, 90-96. [CrossRef]

38. Zlatina, K.; Lutteke, T.; Galuska, S.P. Individual Impact of Distinct Polysialic Acid Chain Lengths on the Cytotoxicity of Histone H1, H2A, H2B, H3 and H4. Polymers 2017, 9, 720. [CrossRef]

39. Galuska, S.P.; Galuska, C.E.; Tharmalingam, T.; Zlatina, K.; Prem, G.; Husejnov, F.C.O.; Rudd, P.M.; Vann, W.F.; Reid, C.; Vionnet, J.; et al. In vitro generation of polysialylated cervical mucins by bacterial polysialyltransferases to counteract cytotoxicity of extracellular histones. FEBS J. 2017, 284, 1688-1699. [CrossRef]

40. Galuska, C.E.; Dambon, J.A.; Kuhnle, A.; Bornhofft, K.F.; Prem, G.; Zlatina, K.; Lutteke, T.; Galuska, S.P. Artificial Polysialic Acid Chains as Sialidase-Resistant Molecular-Anchors to Accumulate Particles on Neutrophil Extracellular Traps. Front. Immunol. 2017, 8, 1229. [CrossRef]

41. Nakata, D.; Troy, F.A., II. Degree of polymerization (DP) of polysialic acid (polySia) on neural cell adhesion molecules (N-CAMS): Development and application of a new strategy to accurately determine the DP of polySia chains on N-CAMS. J. Biol. Chem. 2005, 280, 38305-38316. [CrossRef]

42. Galuska, S.P.; Geyer, H.; Bleckmann, C.; Röhrich, R.C.; Maass, K.; Bergfeld, A.K.; Mühlenhoff, M.; Geyer, R. Mass spectrometric fragmentation analysis of oligosialic and polysialic acids. Anal. Chem. 2010, 82, 2059-2066. [CrossRef] [PubMed] 
43. Inoue, S.; Inoue, Y. Ultrasensitive analysis of sialic acids and oligo/polysialic acids by fluorometric high-performance liquid chromatography. Methods Enzym. 2003, 362, 543-560.

44. Hara, S.; Yamaguchi, M.; Takemori, Y.; Furuhata, K.; Ogura, H.; Nakamura, M. Determination of mono-O-acetylated $\mathrm{N}$-acetylneuraminic acids in human and rat sera by fluorometric high-performance liquid chromatography. Anal. Biochem. 1989, 179, 162-166. [CrossRef]

45. Hara, S.; Takemori, Y.; Yamaguchi, M.; Nakamura, M.; Ohkura, Y. Fluorometric high-performance liquid chromatography of $\mathrm{N}$-acetyl- and N-glycolylneuraminic acids and its application to their microdetermination in human and animal sera, glycoproteins, and glycolipids. Anal. Biochem. 1987, 164, 138-145. [CrossRef]

46. Galuska, S.P.; Geyer, H.; Weinhold, B.; Kontou, M.; Röhrich, R.C.; Bernard, U.; Gerardy-Schahn, R.; Reutter, W.; Münster-Kühnel, A.; Geyer, R. Quantification of Nucleotide-Activated Sialic Acids by a Combination of Reduction and Fluorescent Labeling. Anal. Chem. 2010, 82, 4591-4598. [CrossRef] [PubMed]

47. Bayer, N.B.; Schubert, U.; Senturk, Z.; Rudloff, S.; Frank, S.; Hausmann, H.; Geyer, H.; Geyer, R.; Preissner, K.T.; Galuska, S.P. Artificial and natural sialic acid precursors influence the angiogenic capacity of human umbilical vein endothelial cells. Molecules 2013, 18, 2571-2586. [CrossRef]

48. Saffarzadeh, M.; Juenemann, C.; Queisser, M.A.; Lochnit, G.; Barreto, G.; Galuska, S.P.; Lohmeyer, J.; Preissner, K.T. Neutrophil extracellular traps directly induce epithelial and endothelial cell death: A predominant role of histones. PLoS ONE 2012, 7, e32366. [CrossRef] [PubMed]

49. Kenny, E.F.; Herzig, A.; Kruger, R.; Muth, A.; Mondal, S.; Thompson, P.R.; Brinkmann, V.; Bernuth, H.V.; Zychlinsky, A. Diverse stimuli engage different neutrophil extracellular trap pathways. Elife 2017, 6, e24437. [CrossRef]

50. Lohrke, B.; Xu, J.; Weitzel, J.M.; Kruger, B.; Goldammer, T.; Viergutz, T. N-acetylcysteine impairs survival of luteal cells through mitochondrial dysfunction. Cytometry A 2010, 77, 310-320. [CrossRef]

51. Rohm, M.; Grimm, M.J.; D’Auria, A.C.; Almyroudis, N.G.; Segal, B.H.; Urban, C.F. NADPH oxidase promotes neutrophil extracellular trap formation in pulmonary aspergillosis. Infect. Immun. 2014, 82, 1766-1777. [CrossRef] [PubMed]

52. Seligmann, B.E.; Gallin, J.I. Use of lipophilic probes of membrane potential to assess human neutrophil activation. Abnormality in chronic granulomatous disease. J. Clin. Investig. 1980, 66, 493-503. [CrossRef]

53. Whitin, J.C.; Clark, R.A.; Simons, E.R.; Cohen, H.J. Effects of the myeloperoxidase system on fluorescent probes of granulocyte membrane potential. J. Biol. Chem. 1981, 256, 8904-8906. [PubMed]

54. Henderson, L.M.; Chappell, J.B.; Jones, O.T. The superoxide-generating NADPH oxidase of human neutrophils is electrogenic and associated with an H+ channel. Biochem. J. 1987, 246, 325-329. [CrossRef]

55. Cohen, H.J.; Newburger, P.E.; Chovaniec, M.E.; Whitin, J.C.; Simons, E.R. Opsonized zymosan-stimulated granulocytes-activation and activity of the superoxide-generating system and membrane potential changes. Blood 1981, 58, 975-982. [PubMed]

56. Castranova, V.; Jones, G.S.; Phillips, R.M.; Peden, D.; Vandyke, K. Abnormal responses of granulocytes in chronic granulomatous disease. Biochim. Biophys. Acta 1981, 645, 49-53. [CrossRef]

57. Hakkim, A.; Fuchs, T.A.; Martinez, N.E.; Hess, S.; Prinz, H.; Zychlinsky, A.; Waldmann, H. Activation of the Raf-MEK-ERK pathway is required for neutrophil extracellular trap formation. Nat. Chem. Biol. 2011, 7, 75-77. [CrossRef] [PubMed]

58. Okubo, K.; Kamiya, M.; Urano, Y.; Nishi, H.; Herter, J.M.; Mayadas, T.; Hirohama, D.; Suzuki, K.; Kawakami, H.; Tanaka, M.; et al. Lactoferrin Suppresses Neutrophil Extracellular Traps Release in Inflammation. EBioMedicine 2016, 10, 204-215. [CrossRef]

59. Kühnle, A.; Veelken, R.; Galuska, C.E.; Saftenberger, M.; Verleih, M.; Schuppe, H.-C.; Rudloff, S.; Kunz, C.; Galuska, S.P. Polysialic acid interacts with lactoferrin and supports its activity to inhibit the release of neutrophil extracellular traps. Carbohydr. Polym. 2019, 208, 32-41. [CrossRef]

60. Janas, T.; Nowotarski, K.; Janas, T. Polysialic acid can mediate membrane interactions by interacting with phospholipids. Chem Phys Lipids 2010, 163, 286-291. [CrossRef]

61. Sapon, K.; Janas, T.; Sikorski, A.F.; Janas, T. Polysialic acid chains exhibit enhanced affinity for ordered regions of membranes. Biochim. Biophys. Acta 2018, 1861, 245-255. [CrossRef] [PubMed]

(C) 2019 by the authors. Licensee MDPI, Basel, Switzerland. This article is an open access article distributed under the terms and conditions of the Creative Commons Attribution (CC BY) license (http://creativecommons.org/licenses/by/4.0/). 